\title{
Application of photovoltaic technology in the use of solar
}

\section{energy}

\section{Andjela B Stanojevic*}

Faculty of Environmental Sciences, Study Program, Environmental Engineering, Czech University of

Life Sciences, Prague, Czech Republic

Received: 23 July, 2021

Accepted: 03 August, 2021

Published: 04 August, 2021

*Corresponding author: Andjela B Stanojevic, Faculty of Environmental Sciences, Study Program, Environmental Engineering, Czech University of Life Sciences, Prague, Kamycka 129, 16521 Prague 6, Suchdol, Czech Republic, Tel: +38163436436, +420776521504; Fax: +381113572835 ;

E-mail: xstaa030@studenti.czu.cz

ORCID: https://orcid.org/0000-0001-6258-4118

Keywords: Solar energy; Solar panels; Photovoltaic technology; Renewable resource

https://www.peertechzpublications.com

\section{Abstract \\ Solar heating and cooling, concentrating solar power and photovoltaic are three solar technologies which harness solar energy. Photovoltaic Technology (PV) is directly converting sunlight into electricity and it is very convenient to use. In addition, these devices are simple in design and easy to handle. The efficiency of energy production this way is great. In order to obtain constant/continuous energy for consumption, the PV system can be a part of the so-called hybrid system. In the hybrid system, the PV system is combined with other renewable or non-renewable energy sources. However, there are certain problems in the use of solar energy, such as: cost, maintenance of the entire system and the impact of maintenance on the ecosystem, as well as the development of consumer awareness. Today, the world is forced to solve these problems in order to be able to save the planet from further deterioration of the ecosystem.}

\section{Introduction}

In the twenty-first century, energy systems are making tremendous progress [1]. Industrialization revolution brought expeditious population increase and with that economic development, that resulted in increasing energy demand and dependency of population on fuels for myriad uses which causes forceful depletion of unrenewable resources offered within the world. A large part of electricity (77.9\%) is generated primarily from fossil fuels, as well as from nuclear sources. These energy sources are expensive and large environmental pollutants (due to the production of toxic gases and the creation of the "greenhouse" effect) [2]. This leads to very serious negative global climate changes and consequences for the environment, such as melting ice and rising water levels on the planet. The use of fossil fuels and their exploitation leads to serious problems in the natural balance, which leads to ecosystem damage [3]. Therefore, greater efforts should be made to increase the use of renewable energy sources globally [4]. Today it is a great challenge to provide the necessary amounts of sustainable and clean energy on a global level. The future is energy technologies that will use renewable energy sources (biomass, wind or solar) [1]. Many studies have shown that global energy needs can be met through the use of solar energy, since it is abundant in nature and is a freely accessible energy source at no cost [5].

The aim of this paper was to explain the basic principles of photovoltaic technology and the possibilities of its application in the use of solar energy with the aim of obtaining electricity.

\section{Solar energy}

Solar energy is solar radiation that can generate heat, generate electricity, or cause chemical reactions. Total availability and possibility of using solar energy on Earth far exceeds the current and forecast energy needs of the world [6]. Several reasons suggest that the use of solar energy could be very good for the future. First, this is a renewable and easily accessible source of energy, which the Sun emits at high speed $(3.8 \times 1023 \mathrm{~kW})$, of which a large part is available on Earth $(1.8 \times 1014 \mathrm{~kW})[7]$. Second, the energy of the Sun is practically inexhaustible and therefore provides many possibilities as a source of energy [8]. Third, the use and monitoring of solar energy has no harmful effects on the ecosystem. Fourth, the 
solar energy production system can be used efficiently in urban and rural areas, in industrial and domestic conditions, because it is easily accessible and usable. These characteristics show that the proper use of solar technology in the future would be the best option, in order to avoid unwanted consequences for the environment as well as the occurrence of energy shortages [9].

There are three solar technologies that use solar energy: photovoltaics, solar heating and cooling, and concentration of solar energy [10]. When used properly, this highly diffused source can cover all future energy requirements [6]. Since this is a very broad field of research, this article will mainly focus on photovoltaic solar technology.

\section{Fundamentals of photovoltaic technology}

The goal of Photovoltaic Technology (PV) is to convert sunlight directly into electricity without an interface for the conversion. This equipment is simple in design and easy to handle [11]. Besides that, a small stake can lead to significant results. Yet, its system remains to be promoted for higher results.

The PV-solar cell is the basic unit of a PV-system and consists of an association between two thin layers of different semiconductor materials, which are the only materials that absorb the energy of photons from sunlight. One is the positive (P-type) and the other is the negative (N-type) semiconductor [12]. Silicon is most commonly used to make PV-solar cells, because of its suitability and efficiency. Silicon may be microcrystalline, polycrystalline or monocrystalline. However, in addition to silicon, other materials for semiconductor design can be used in PV-systems, such as: cadmium-telluride and copper-indium-diselenide (Figure 1). Which material will be used depends on several factors [13]. P-type semiconductors are made from crystalline silicon doped with a very small amount of an impurity (e.g. boron), making the material electron deficient. $\mathrm{N}$-type semiconductors also consist of crystalline silicon, but doped with small amounts of another impurity (e.g. phosphor) so these materials have an excess of free electrons [12] (Figure 2).

The principle of PV-system is that by adding energy, electrons are activated in a semiconductor. Namely, with the addition of sunlight energy, the electrons of the PV-system are activated and pass from a lower energy state to a higher energy state. This leads to the generation of electricity, in a semiconducto [14] (Figure 3).

A PV-system consists of several parts, such as PV-cells, electrical and mechanical assemblies as well as means for changing or / and regulating the electrical power (Figure 4).

PV-systems are classified in terms of "peak kilowatts" (kWp). "Peak kilowatts" are the amount of electricity that PVsystem delivers in the conditions of a clear day, when the Sun is directly above the head [15].

The electricity generated by the PV-technology is fed into the grid systems. In this way the efficiency of grid systems is

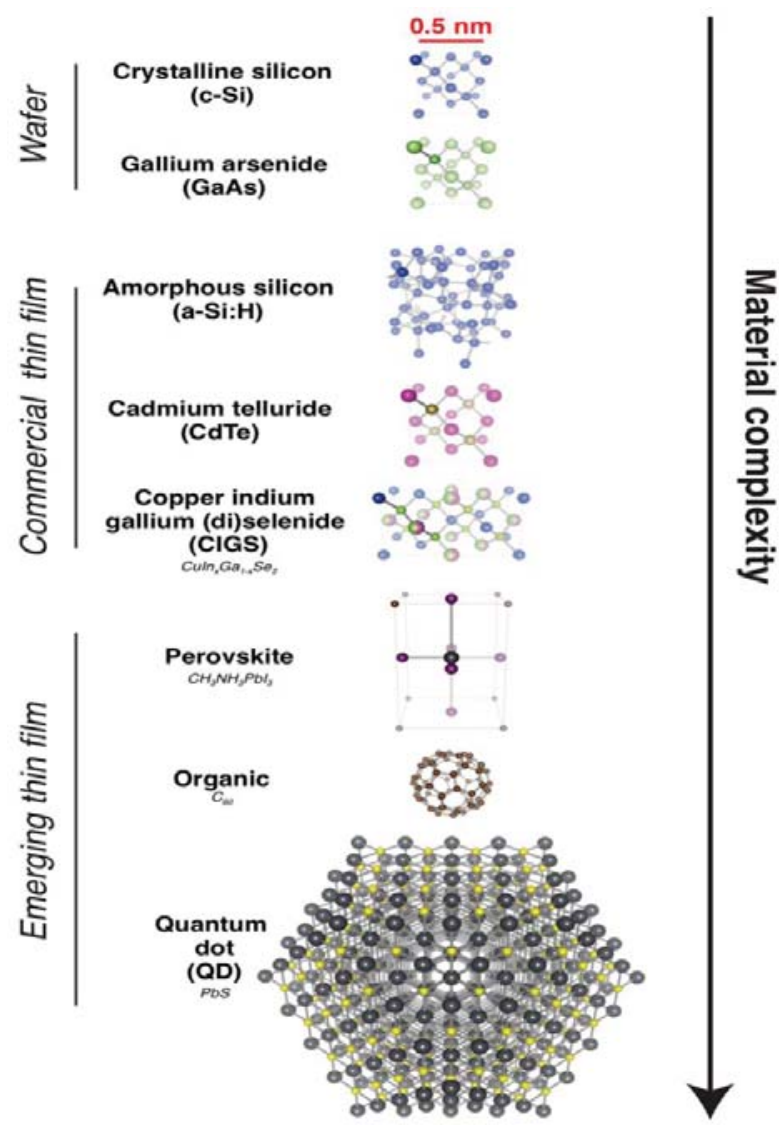

Figure 1: Classifying PV technologies based on material complexity [26].

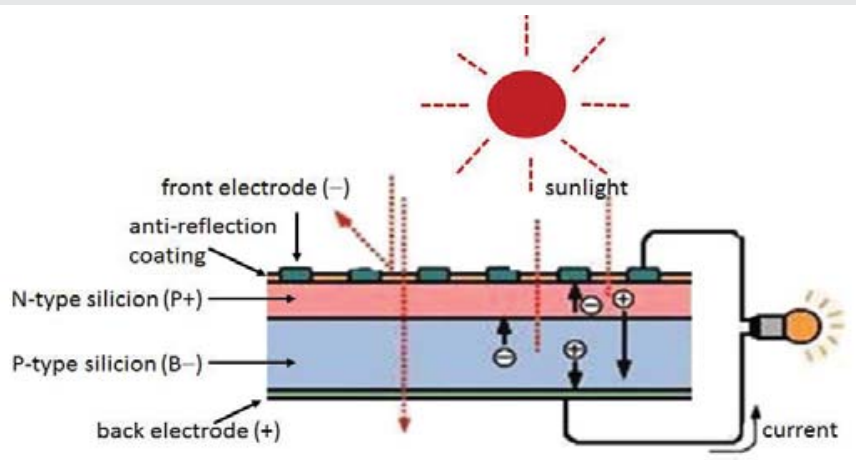

Figure 2: Diagram of solar cell [27]

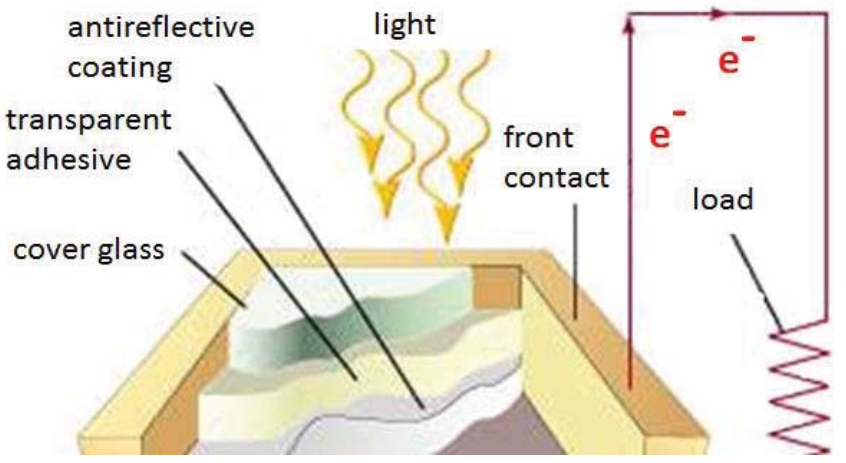

Figure 3: Schematic of solar cell. Due to the photoelectric effect, an electron is released when sunlight reaches a solar cell. There are two semiconductors with different voltage (potential) in the solar cell. Electrons pass through the outer circuit, supplying power to the load [6].

Citation: Stanojevic AB (2021) Application of photovoltaic technology in the use of solar energy. Ann Environ Sci Toxicol 5(1): 094-098. 
increased. Electricity supply with this system is possible in two ways: 1) from the grid to the user's home and 2) from the user's house to the grid. These modalities of use make this solar system very useful and easy to apply. The system works by first installing solar panels on the user's house and connecting them to the electrical network. Solar panels convert solar energy into Direct Current (DC). This electricity is then sent to a solar inverter, which translates direct current into Alternating Current (AC). Electrical appliances in the consumer's home are powered by this alternating current (Figure 4). This electricity is also supplied to the grid and is thus available for everyday use. Because in this way the total energy produced is usually much higher than what a household needs, the solar converter regulates the voltage and the amount of electricity supplied to the household. The network meter is a significant feature. It is a tool that records the energy supplied to the network and the energy consumption. Network meter is a tool that records the energy consumption and the energy supplied to the network. In this way, the remaining amount of energy is recorded and a bill is sent to the consumer at the end of each month [16] (Figure 5).

About $90 \%$ of the electricity produced by the PV-system is connected to the grid system. This network system can be installed on the roofs or walls of buildings, as well as under the ground. The shelf life varies depending on the maintenance conditions. A well-developed PV-module can function satisfactorily for up to 25 years with a capacity of $80 \%$ and 10 years with a capacity of $90 \%$ [17].

\section{Efficiency of photovoltaic panels}

PV-panels may be inefficient in collecting all available solar energy due to the fluctuating solar flux. In order to increase the amount of collected available solar energy, the so-called "concept of solar tracking" is applied [18]. Single-axis and dual-axis solar tracking systems can be applied in the "solar tracking concept" (Figure 6). The tracker is a device that increases the collected solar energy by, in daylight, keeping the thermal photovoltaic modules in the optimal position perpendicular to the solar radiation [19]. The concentration of available solar radiation is associated with solar trackers and

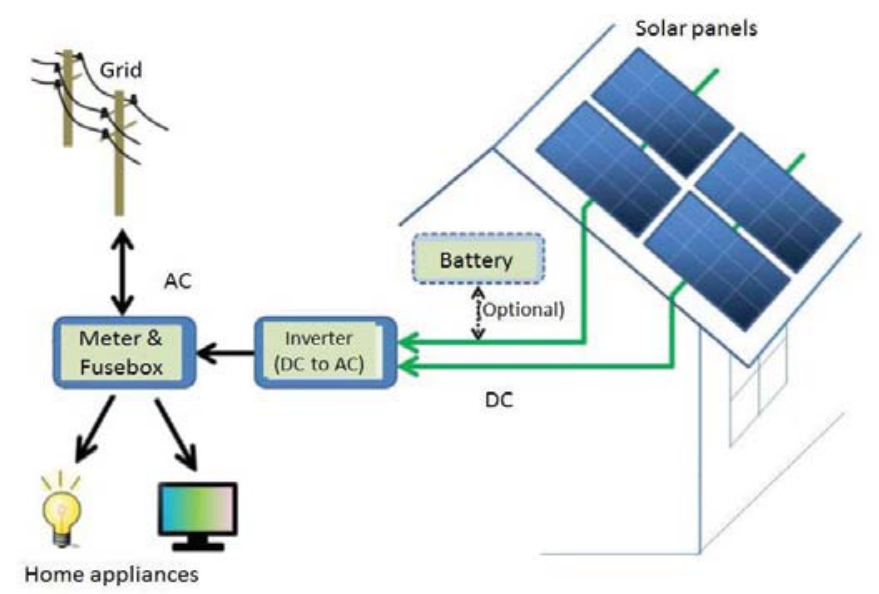

Figure 4: Schema of a simple photovoltaic solar power system (typical grid connected). DC-direct current; AC-alternating current. [28].

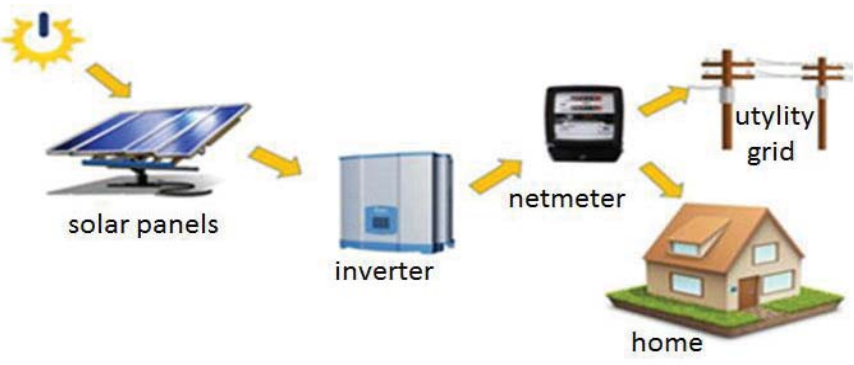

Figure 5: Schematic of a grid solar power system [16].
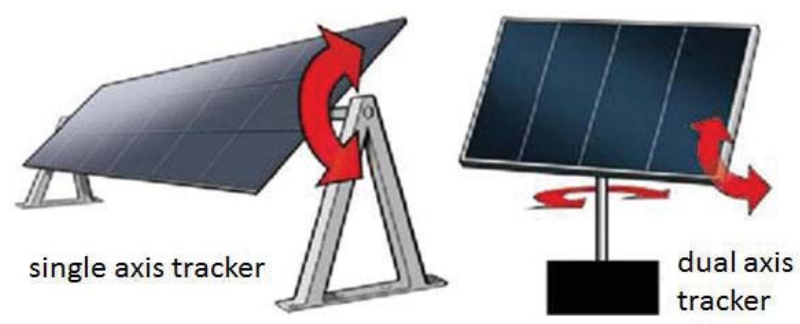

Figure 6: One axis and two axis systems of solar panels [29]

PV modules according to the movement of solar energy to get substantial solar energy than fixed photovoltaic modules.

\section{Hybrid photovoltaic power generation}

Hybrid power systems can be used in cases where photovoltaic modules have difficulty generating constant power for consumption [20]. This system combines a one renewable energy source (e.g. PV- system) with other forms of renewable energy generation (e.g. wind), even with form of a conventional generator running on diesel (Figure 7). In this case, the use of hybrid systems reduces the consumption of non-renewable fuels [15]. Hybrid systems can be positively integrated to make the power system consistent without disrupting the daily activities of the domestic sectors.

\section{Photovoltaic efficiency}

The power of a PV system to convert sunlight into useful energy is measured by the efficiency of PV solar panels. For the correct installation of the PV system, it is very important to know the efficiency of the PV panel, which is calculated as follows [12]:

$$
\eta_{\max }(\text { maximum efficiency })=\frac{P_{\max }(\text { maximum power output })}{\left.\left(E_{S, \gamma}^{S W}(\text { incident radiation flux }) * A_{C} \text { (area of collector }\right)\right)}
$$

\section{Barriers of solar industry}

Despite the fact that the solar industry has developed rapidly in recent years, there are still some significant hurdles to overcome. First, solar PV-technology is expensive and complicated, and requires advanced technology to manufacture and install [21]. Namely, the PV system has a high capital cost compared to other conventional energy sources. Therefore, the optimization of the PV system must be performed in terms of the correct choice of the number of PV modules, the capacity of 


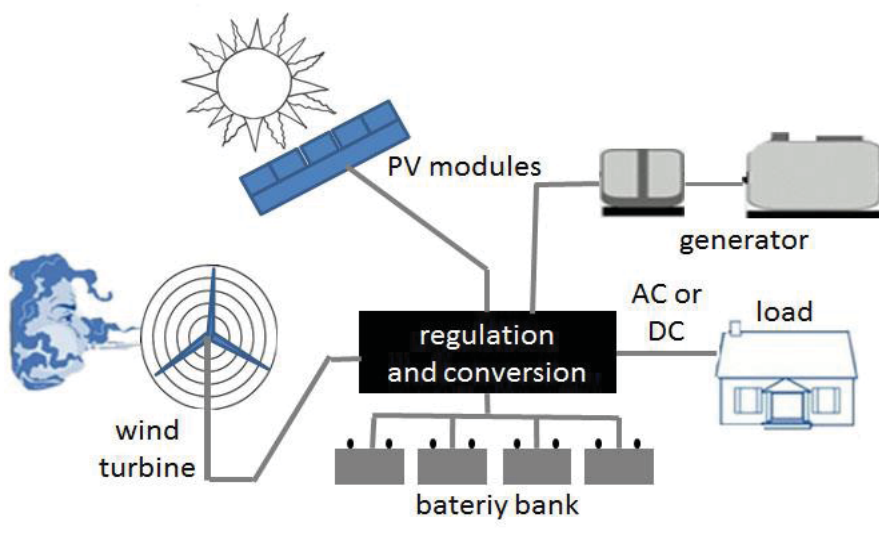

Figure 7: Wind/Diesel/PV hybrid solar system [30].

the converter and the battery, as well as the wind turbine and the size of the diesel generator. Second, the efficiency of solar panels is strongly influenced by a number of environmental factors, in particular the intensity of the sun, cloud cover and wind speed [22]. Third, there is low awareness of the potential benefits of the solar industry especially among the rural population around the world because their literacy rate is low. Fourth, the development of solar energy projects is affected by competition from other markets and blocks its development. Fifth, solar cells are mainly composed of materials that are toxic to the environment, which is a problem for users and producers of solar energy [23]. Sixth, the generation of solar energy is not steady. Therefore, the combination of other energy sources into electrical grid systems is very important to keep the supply constant. Seventh, large PV-systems can cause some undesirable environmental impacts (e.g. birds may be killed as they fly) [24]. Eighth, for cooling and clean turbine generators huge amount of water is used. This results in wastage of water and the creation of large amounts of wastewater.

Despite those issues, growing reliance on sun and different varieties of renewable strength must to be our essential aim withinside the future [20]. Today researchers are running at excessive velocity to conquer those issues and permit higher manufacturing efficiencies.

\section{Challenges and future perspectives}

Several issues significantly affect the performance of the PV system. First, data handling can be a problem in implementation PV system. Conventional technology is not able to control the large amount of data generated with the increase of solar power plants. Therefore, a powerful system needs to be developed that is able to monitor a large amount of data in real time. Second, security is an important aspect of a wireless monitoring system. Poor security can compromise system functionality. Protection, privacy and confidentiality should be ensured, as well as compliance with security protocols. Third, there may be problems with signal interference. This can cause problems in monitoring the data of the solar PV system. Signal interference can lead to slow data transfer, poor module operation, as well as poor signal strength and disconnection. This all reduces the quality of service and increases the loss of revenue. Fourth, the energy efficiency of a PV-system depends on the lifespan of the node battery. Namely, the PV system consists of multiple nodes of transmitters. Each node battery failure leads to a shorter lifespan of the PV-network. Fifth, the operating system and programming language must be user-friendly. Sixth, the range of data transmission must be appropriate for a particular PV system. This is especially important for systems where the distance between the two furthest PV panels can be in $\mathrm{km}$. A long-range data transmission platform should not suffer from low transmission speeds. Seventh, the environmental influences on the PV system (for example, dust, temperature, radiation, humidity) are very important for the proper functioning of the system. They should be handled very carefully when installing PV panels in an open environment. For example, the deposition of dust reduces the intensity of sunlight captured by solar cells on the PV panel. Eighth, the accuracy of the transmission module can be affected by different electromagnetic and radio signals. Therefore, compatible shield-modules integrated with data transmission boards should be developed. Ninth, the efficiency of different solar cell technologies is different and significantly depends on the substance from which it was made (e.g. mono-crystalline silicon, poly-crystalline silicon, amorphous silicon, thin-film copper indium disulfide, heterojunction incorporating thin film). Therefore, the appropriate solar cell technology should be selected in order to achieve optimal efficiency [25].

As the size and application of solar PV systems increase, in the future we should work on improving data handling, increasing efficiency, security and transmission range, as well as reducing signal interference. Namely, one should try to avoid all nine problems mentioned above. In fact, in the future, efforts should be made to develop a reliable state-of-the-art wireless network monitoring system [25].

\section{Conclusion}

The use of fossil fuels causes damage to ecosystems as well as the balance in nature. Solar energy could be the best option for the future because: it is the large and inexhaustible energy source, excessive handling it does not have any harmful impact on the environment and it is easily applicable (in village / urban system as well as in industrial systems). In that sense, photovoltaic technology, which directly converts sunlight into electricity, is very convenient to use. Especially since these devices are very easy to handle and simple in construction. Briefly, the PV system works on the principle of using sunlight, as a result of which the electrons are activated and move from a lower to a higher electronic state, during which electricity is formed. The PV-system can work well for up to 25 years with $80 \%$ capacity or 10 years with $90 \%$ capacity. The increase in efficiency is achieved by the possibility of adjusting the displacement of the PV panel according to the motion of the solar. The PV system is suitable for combining with other renewable (e.g. wind) or non-renewable (e.g. diesel) sources in order to obtain consistent energy for consumption. These are so-called hybrid systems. In addition to significant advantages, solar energy production has its drawbacks, such as: cost, maintenance of the entire system and the impact of 
maintenance on the ecosystem, as well as the development of consumer awareness. However, we must be aware that overcoming these problems leads the world to the necessary protection of the environment. Are we really aware that this is necessary today?

\section{References}

1. Foster R, Ghassemi M, Cota A (2009) Solar energy: Renewable energy and the environment. $1^{\text {st }}$ Edition. Eds: Cota A, Foster R, Ghassemi M. Taylor \& Francis eBooks. CRC Press.

2. Renewables global status report (2014) Secretariat renewable energy policy Network for the $21^{\text {st }}$ century (REN21) Paris. Link: https://bit.ly/3lpgyCN

3. Schlamadinger B, Apps M, Bohlin F, Gustavsson L, Jungmeier G, et al. (1997) Towards a standard methodology for greenhouse gas balances of bioenergy systems in comparison with fossil energy systems. Biomass Bioenerg 13: 359-375. Link: https://bit.ly/3A3g8WT

4. Roper LD (2012) Future world energy. Link: https://bit.ly/2Vsos3m

5. Lewis NS (2007) Toward cost-effective solar energy use. Science 315: 798801. Link: https://bit.ly/3rRyYgE

6. Ashok S (2020) Solar energy. Encyclopedia Britannica. Link: https://bit.ly/3A2Ol8V

7. Panwar N, Kaushik S, Kothari S (2011) Role of renewable energy sources in environmental protection: a review. Renew Sust Energ Rev 15: 1513-1524. Link: https://bit.ly/3ypuEbg

8. Nozik AJ (1978) Photoelectrochemistry: applications to solar energy conversion. Annu Revof Phys Chem 29: 189-222. Link: https://bit.ly/3ijo3cE

9. Armaroli N, Balzani $V$ (2007) The future of energy supply: challenges and opportunities. Angew Chem Int Edit 46: 52-66. Link: https://bit.ly/3zYWpaO

10. Solar Energy Industries Association (SEIA). Solar Energy. Link: https://bit.ly/3fqBWE6

11. Barker PP, Bing JM (2005) Advances in solar photovoltaic technology: an applications perspective, Conference Paper. In: Presented at IEEE Power Engineering Society Summer Meeting. Link: https://bit.ly/2VgeQZX

12. Khan KA, Paul S, Zobayer A, Hossain SS (2013) A Study on solar photovoltaic conversion. International Journal of Scientific and Engineering Research 4: 1-5. Link: https://bit.ly/3ltAZP4

13. Razykov T, Ferekides CS, Morel D, Stefanakos E, Ullal HS, et al. (2011) Solar photovoltaic electricity: current status and future prospects. Solar Energy 85: 1580-1608. Link: https://bit.ly/3ltBbxM

14. Green MA (2002) Photovoltaic principles. Physica E Low-dimensional Systems and Nanostructures 14: 11-17. Link: https://bit.ly/2WFCq2w

15. Parida B, Iniyanb S, Goicc R (2011) A review of solar photovoltaic technologies. Renew Sust Energ Rev 15: 1625-1636. Link: https://bit.ly/3CaXnm7

16. How an on- grid solar power system works? Link: https://bit.ly/3A4hAse

17. Devabhaktuni V, Alam M, Depuru SSSR, Green II RC, Nims D, et al. (2013) Solar energy: trends and enabling technologies. Renew Sust Energ Rev 19: 555564. Link: https://bit.ly/3yllL25

18. Helwa NH, Bahgat ABG, El Shafee AMR, El Shenawy ET (2000) Maximum collectable solar energy by different solar tracking systems. Energ Source 22: 23-34. Link: https://bit.ly/2Vgfqa5
19. Roth P, Georgiev A, Boudinov H (2005) Cheap two axis sun following device. Energ Convers Manage 46: 1179-1192. Link: https://bit.ly/3A5jlFC

20. Kannan N, Vakeesan D (2016) Solar energy for future world: A review. Renew Sust Energ Rev 62: 1092-1105. Link: https://bit.ly/3xkw0CJ

21. Ciarreta A, Espinosa MP, Pizarro-Irizar C (2014) Is green energy expensive? Empirical evidence from the Spanish electricity market. Energ Policy 69: 205215. Link: https://bit.ly/3ykMThO

22. Hernandez R, Easter SB, Murphy-Mariscal ML, Maestre FT, Tavassoli M, et al. (2014) Environmental impacts of utility-scale solar energy. Renew Sust Energ Rev 29: 766-779. Link: https://bit.ly/3fso8sD

23. Li J (2011) Nitride-based multi-junction solar cell modules and methods for making the same. Google Patents, US20110011438A1, United States. Link: https://bit.ly/3rNvfku

24. Wu Z, Hou A, Chang C, Huang X, Shib D, et al. (2014) Environmental impacts of large-scale CSP plants in northwestern China. Envirion Sci Process Impacts 16: 2432-2441. Link: https://bit.ly/3ilYfNe

25. Ansari S, Ayob A, Hossain Lipu SM, Hanif Md Saad M, Hussain A (2021) A review of monitoring technologies for solar PV systems using data processing modules and transmission protocols: progress, challenges and prospects Sustainability 13: 8120. Link: https://bit.ly/3rX1mOD

26. Stauffer WN (2015) Solar photovoltaic technologies. Silicon and beyond. Link: https://bit.ly/3A6bibk

27. Su Q, Zhang G, Lai J, Feng S, Shi W (2010) Green solar electric vehicle changing the future lifestyle of human. World Electric Vehicle Journal 4: 128-132. Link: https://bit.ly/3A4s1vP

28. Solar Power System - How Does It Work? Link: https://bit.ly/3C50Gd7

29. Kumar ES, Sarkar B (2013) Impact of wind and shading on energy contribution by photovoltaic panels with axis tracking system. International Conference on Microelectronics, Communication and Renewable Energy (ICMiCR-2013). https://bit.ly/3A5kAog

30. Energy gov (2012) U.S. Department of Enargy.

\section{Discover a bigger Impact and Visibility of your article publication with}

\section{Peertechz Publications}

\section{Highlights}

* Signatory publisher of ORCID

* Signatory Publisher of DORA (San Francisco Declaration on Research Assessment)

* Articles archived in worlds' renowned service providers such as Portico, CNKI, AGRIS, TDNet, Base (Bielefeld University Library), CrossRef, Scilit, J-Gate etc.

* Journals indexed in ICMJE, SHERPA/ROMEO, Google Scholar etc.

* OAI-PMH (Open Archives Initiative Protocol for Metadata Harvesting)

* Dedicated Editorial Board for every journa

* Accurate and rapid peer-review process

* Increased citations of published articles through promotions

* Reduced timeline for article publication

Submit your articles and experience a new surge in publication services (https://www.peertechz.com/submission).

Peertechz journals wishes everlasting success in your every endeavours.

Copyright: @ 2021 Stanojevic AB. This is an open-access article distributed under the terms of the Creative Commons Attribution License, which permits unrestricted use distribution, and reproduction in any medium, provided the original author and source are credited.

Citation: Stanojevic AB (2021) Application of photovoltaic technology in the use of solar energy. Ann Environ Sci Toxicol 5(1): 094-098. DOI: https://dx.doi.org/10.17352/aest.000044 